\title{
Eksistensi Negeri Ambon dan Nagari Sumatera Barat Pasca Pemberlakuan Undang-Undang Desa
}

\author{
Sri Wahyuni \\ Fakultas Syari'ah dan Hukum UIN Sunan Kalijaga Yogyakarta Indonesia \\ Jln. Marsda Adisucipto Yogyakarta Indonesia \\ nee_cyk@yahoo.com
}

Received: 29 April 2021; Accepted: 17 Desember 2021; Published: 31 Januari 2022

DOI: 10.20885/iustum.vol29.iss1.art10

\begin{abstract}
In some parts of Indonesia, the community structure and government are still strictly adhered to the customary system, such as in West Sumatra and the Ambon Maluku area. With the implementation of a modern government system in the form of the village as the lowest government under the Camat, based on Law Number 5 of 1979 on Village Government, the customary community unit underwent many changes. This study discusses the existence of traditional villages after Law Number 6 of 2014 on Villages. The formulation of the research problem is how is the existence of the State in Ambon City and Nagari in West Sumatra as a traditional village after the implementation of the Village Law and how is the traditional village system viewed from the modern constitutional system in Indonesia? This is a field research that focuses on the state in Ambon and Nagari in West Sumatra, by using a comparative model and a sociological approach as well as an empirical legal research. The results of the study conclude that the Village Law has accommodated traditional villages with the right of origin over their structure. Likewise, traditional villages in Ambon country which have a King, Saniri Negeri, Soa, Fam, Kewang and Marinyo, and in West Sumatra Nagari have Nagari Customary Density Guardians and Nagari Consultative Body. In these traditional villages, there are customary values that have changed due to the influence of democracy and Indonesia's modern state system. That being the king and guardian of the village who are directly elected. The function of customary institutions in the settlement of customary cases is also diminished due to the existence of the Indonesian national legal system.
\end{abstract}

Key Words: State; Nagari; Village Law

\section{Abstrak}

Di beberapa wilayah Indonesia, struktur masyarakat dan pemerintahannya masih ketat dengan sistem adat, seperti di Sumatera Barat dan daerah Ambon Maluku. Dengan diberlakukannya sistem pemerintahan modern berupa desa sebagai pemerintahan terendah di bawah Camat, berdasarkan Undang-Undang Nomor 5 Tahun 1979 tentang pemerintah Desa, maka satuan masyarakat adat tersebut mengalami banyak perubahan. Penelitian ini membahas tentang eksistensi desa adat setelah Undang-Undang Nomor 6 Tahun 2014 tentang Desa. Adapun rumusan masalah penelitian ini yaitu bagaimanakah eksistensi Negeri di Kota Ambon dan Nagari Sumatera Barat sebagai desa adat pasca pemberlakukan Undang-undang Desa dan bagaimana sistem desa adat tersebut ditinjau dari sistem ketatanegaraan modern di Indonesia? Penelitian ini merupakan penelitian lapangan yang mengambil fokus pada negeri di Ambon dan Nagari di Sumatera Barat, dengan mengunakan model perbandingan, dan pendekatan sosiologis, serta merupakan penelitian hukum empiris. Hasil penelitian menyimpulkan bahwa Undang-Undang Desa telah mengakomodasi desa adat dengan adanya hak asal usul atas strukturnya. Begitu juga desa adat pada negeri Ambon yang memiliki Raja, Saniri Negeri, Soa, Fam, Kewang dan Marinyo, serta pada nagari Sumatera Barat memiliki Wali Nagari Kerapatan Adat Nagari dan Badan Musyawarah Nagari. Dalam desa adat ini, terdapat nilai-niai adat yang berubah karena pegaruh demokrasi dan sistem ketetanegaraan modern Indonesia. Seperti adanya Raja dan wali nagari yang dipilih secara langsung. Fungsi lembaga-lembaga adat dalam penyelesaian perkara adat juga semakin berkurang karena adanya sistem hukum nasional Indonesia.

Kata-kata Kunci: Negeri; nagari; undang-undang desa 


\section{Pendahuluan}

Struktur masyarakat dan pemerintahan di beberapa wilayah Indonesia saat ini masih ketat dengan sistem adat, seperti di Sumatera Barat, Bali, dan daerah Ambon Maluku. Di Sumatera Barat, semua wilayah kabupaten, tingkat struktur masyarakat terendahnya disebut nagari yaitu struktur pemerintahan desa adat, hanya di wilayah kota saja yang menggunakan struktur kelurahan. Nagari terdiri dari beberapa jorong (yang sepadan dengan RT dan RW) atau dukuh dalam struktur desa. ${ }^{1}$

Begitu juga di hampir seluruh kawasan wilayah Maluku dikenal kuat rezim adat, yang dikenal dengan pemerintahan negeri. Negeri merupakan suatu persekutuan teritorial yang memiliki batas wilayah darat dan laut yang jelas. Negeri bersifat geneologis dan dikepalai oleh seorang Raja, dan didampingi oleh Saniri Negeri (semacam badan legislatif Negeri). ${ }^{2}$ Masyarakat asli Maluku menamakan diri mereka sebagai Anak Negeri Maluku. Secara umum Anak Negeri Maluku merupakan masyarakat yang memiliki keterkaitan hidup dengan adat, tradisi, kebudayaan, kekerabatan, dan keberagamaannya atau cara hidup beragama yang adatis. ${ }^{3}$

Sebelum UU No. 32 Tahun 2004 tentang Pemerintahan Daerah dan PP No. 72 Tahun 2005 tentang Desa diberlakukan, negeri-negeri di Makulu tersebut maupun desa adat yang ada di Indonesia mengalami keterpurukan dengan berlakunya UU No. 5 Tahun 1979 tentang Pemerintahan Desa. Aturan ini menderogasi keberadaan desa adat, dengan menempatkan desa sebagai kesatuan masyarakat yang mempunyai organisasi pemerintahan terendah langsung di bawah camat dan berhak menyelenggarakan rumah tangga sendiri. Dengan kata lain, aturan ini menghilangkan pengakuan desa adat sebagai kesatuan masyarakat dengan hak-hak asal usulnya.

${ }^{1}$ Hasil observasi di Sumatera Barat tahun 2018 dan 2019. Dalam sebuah artikel juga dijelaskan bahwa nagari merupakan masyarakat asli di Minangkabau yang dahulu disebut oleh belanda sebagai sebuah negara kecil. Lihat Azwar, W., Yunus, Y., Muliono, M., \& Permatasari, Y. (2018). Nagari Minangkabau: The Study of Indigenous Institutions in West Sumatra, Indonesia. Jurnal Bina Praja: Journal of Home Affairs Governance, 10(2), 231-239. https://doi.org/10.21787/jbp.10.2018.231-239. Lihat juga Aulia Rahmat, "Civil Society Nagari Minangkabau: Restrukturisasi Adat dalam Lintasan Kebijakan" dalam Bakaba : Jurnal Sejarah, Kebudayaan dan Kependidikan Vol 8, No 1 (2019); http:/ / journal.stkip-pgri-sumbar.ac.id/index.php/bakaba/article/view/4300

${ }^{2}$ Ziwar Effendi, Hukum Adat Ambon-Lease, (Jakarta: Pradnya Paramita, 1987), hlm. 31, dan 39.

3 Samuel Waileruny, Membongkar Konspirasi di Balike Konflike Maluku, Yayasan Pustaka Obor Indonesia, Jakarta, 2010, hlm. 95. 
Pemerintah Indonesia mulai memberlakukan Undang-Undang Nomor 6 Tahun 2014 tentang Desa (yang selanjutnya disebut Undang-Undang Desa) pada 2014 lalu. Kemunculan aturan baru ini ditanggapi beragam oleh berbagai masyarakat, khususnya masyarakat Negeri di Kota Ambon dan Kabupaten Maluku Tengah. Pasalnya, kedua wilayah yang menjadi basis masyarakat Pemerintahan Negeri terbanyak di Maluku masih mengalami traumatik atas keberlakukan aturan yang diterapkan masa Orde Baru. Di kota Ambon sendiri misalnya, terdapat sekitar 30 Negeri dan 20 kelurahan. ${ }^{4}$

Berdasarkan paparan permasalahan di atas, maka menarik untuk melihat konstruksi Nagari di Sumatera Barat dan Negeri di Ambon sebagai perwujudan desa adat yang masih eksis hingga saat ini, ditinjau dari Undang-Undang Desa dan sistem demokrasi modern. Dua model desa adat ini dikaji karena keduanya masih tetap eksis dengan berbagai dinamikanya hingga saat ini. Keduanya sangat berbeda, sehingga menarik pula untuk dikaji bersamaan dengan perbandingannya.

Penelitian tentang negeri di Maluku sudah banyak dilakukan diantaranya penelitian yang dilakukan oleh Thomas Havye Wattimena tentang Pengawasan Dewan Perwakilan Rakyat Daerah Terhadap Implementasi Peraturan Daerah Nomor 1 Tahun 2006 tentang Negeri di Kabupaten Maluku Tengah, Lembaga Adat Saniri Sebagai Forum Komunikasi dalam Penyelesaian Masalah Publik di Ambon pada 2006. Studi tentang Tinjauan Kedudukan dan Fungsi Kepala Persekutuan Hukum Adat dalam Sistem Pemerintahan Desa Dewasa Ini: Studi di Kabupaten Dati II Maluku oleh JK Matuankottaa dan Darmini Mawardi 2000. Kemudian studi tentang Sengketa Kewenangan antara Pemerintahan Daerah Maluku Tengah dengan Menteri Dalam Negeri: Telaah Putusan Mahkamah Konstitusi Perkara Nomor: 1/SKLN-VIII/2010 oleh Jemmy Jefry Pietersz 2010.

Penelitian yang dilakukan oleh Dewi, Yustina Trihoni Nalesti and Kwik, Jonathan and Watloly, Aholiab 2018, "The Strategic Role of Lembaga Adat Negeri in the Fulfilment of Victims' Rights to Reparation in Post-Conflict Ambon". ${ }^{5}$ Penelitian

\footnotetext{
4 BPS Kota Ambon, Rencana Kerja Pemerintaban Kota Ambon Tabun 2014, hlm. 6.

5 Dewi, Yustina Trihoni Nalesti and Kwik, Jonathan and Watloly, Aholiab, "The Strategic Role of Lembaga Adat Negeri in the Fulfilment of Victims' Rights to Reparation in Post-Conflict Ambon", Udayana Journal of Law and Culture, 1 (2) (2017) pp. 157-180. ISSN 2549-0680; https://ojs.unud.ac.id/index.php/UJLC/article/view
} 
yang dilakukan oleh Dewi, Yustina Trihoni Nalesti and Pandiangan, Andreas and Suroto, Valentinus pada 2020 yang berjudul Revitalisasi Lembaga Adat "Saniri" Sebagai Aktualisasi Otonomi Desa Dalam Rekonsiliasi Pasca Konflik Di Ambon.6 Penelitian ini mengkaji tentang negeri sebagai desa adat dari berbagai permasalahannya seperti pengaturannya hingga peran lembaganya dalam mengatasi konflik.

Penelitian tentang nagari di Sumatera Barat juga telah banyak dilakukan. Misalnya, penelitian yang berjudul Konflik dalam Pemerintahan Nagari: Penelitian di Nagari Padang Sibusuk Kabupaten Sawahlunto Sijunjung Sumatera Barat yang dilakukan oleh Susi Fitria Dewi yang telah diterbitkan dalam ejournal UNP Vol. 5 No. 1 Tahun 2006. Penelitian lain yaitu yang di lakukan oleh Sri Zul Chairiyah dengan judul Nagari Minangkabau Dan Desa di Sumatra Barat", yang menjelaskan mengenai Nagari dan desa mulai dari pengertian sampai struktur pemerintahannya, dengan mengambil contoh wilayah di Kabupaten Tanah Datar yaitu kecamatan Pariangan dan Rambatan. Selain itu penelitian tersebut juga berisi tentang bagaimana pemerintahan desa di Minangkabau sebelum dan sesudah penerapan UU No. 5 Tahun 1979 tentang Pemerintahan Desa.

Penelitian-penelitian di atas, mengkaji tentang nagari dan negeri sebagai desa adat dari berbagai sisi sebelum diundangkannya Undang-Undang Desa. Penelitian ini dapat dikatakan sebagai kelanjutan dari penelitian-penelitian sebelumnya. Penelitian ini membahas tentang eksistensi nagari di Minangkabau Sumatera Barat dan negeri di Ambon sebagai Desa adat pasca berlakunya Undang-Undang Desa; serta tinjauannya dari perspektif ketatanegaraan modern yang terjadi pergulatan dan adaptasi. Aturan lama sejak 1979 masa orde baru, yang kurang mengakomodasi desa adat, hingga 2014 adanya peraturan baru ini, tentunya telah menggeser nilai desa adat yang mengadaptasi nilai tata pemerintahan modern. Oleh karena itu, setelah Undang-Undang Desa mengakomodasi desa adat, maka nagari di Sumatera Barat dan negeri di Ambon mulai menampakkan eksistensinya, walaupun tetap mengadaptasi nilai-nilai tata pemerintahan dan demokrasi modern.

\footnotetext{
${ }^{6}$ Dewi, Yustina Trihoni Nalesti and Pandiangan, Andreas and Suroto, Valentinus (2020) Revitalisasi Lembaga Adat "Saniri" Sebagai Aktualisasi Otonomi Desa Dalam Rekonsiliasi Pasca Konflik Di Ambon, Project Report, Semarang, dalam http://repository.unika.ac.id/23629/
} 


\section{Rumusan Masalah}

Penelitian ini fokus mengkaji tentang: pertama, bagaimana eksistensi Negeri di Kota Ambon dan Nagari Sumatera Barat sebagai desa adat pasca pemberlakukan Undang-Undang Desa? Kedua, bagaimana sistem desa adat tersebut ditinjau dari sistem ketatanegaraan modern di Indonesia?

\section{Tujuan Penelitian}

Adapun tujuan dari penelitian ini adalah: pertama, untuk mengeksplorasi eksistensi Negeri di Kota Ambon dan Nagari Sumatera Barat sebagai desa adat pasca pemberlakukan Undang-Undang Desa. Kedua, untuk menganalisis sistem desa adat tersebut ditinjau dari sistem demokrasi modern di Indonesia.

\section{Metode Penelitian}

Penelitian ini merupakan jenis penelitian hukum empiris dengan pendekatan sosiologis, yang mengambil posisi sebagai penelitian kualitatif dengan model deskriptif analitis komparatif, yaitu dengan membandingkan antara Negeri di Kota Ambon dan Nagari di Sumatera Barat. Penggunaan data dalam penelitian ini adalah data primer dan data sekunder. ${ }^{7}$

Data primer berupa data yang diperoleh langsung dari responden dan narasumber di lapangan, melalui wawancara, yaitu keterangan para Raja sebagai Kepala Negeri di Ambon dan Wali Nagari di Sumatera Barat. Adapun data sekunder menggunakan beberapa sumber data yaitu: pertama, bahan hukum primer, berupa peraturan perundang-undangan tentang otonomi daerah, pemerintahan desa dan pemerintahan Negeri di Maluku dan Sumatera Barat. Kedua, bahan hukum sekunder yang bersumber dari praktik sosial kemasyarakatan Negeri, data-data penelitian, dokumen-dokumen resmi milik Pemerintah Daerah, data-data sosiologis tentang sturktur masyarakat Negeri di Maluku khususnya Negeri-Negeri di kota Ambon dan Nagari-Nagari Sumatera Barat. Ketiga, bahan hukum tersier yang digunakan untuk memperjelas beberapa definisi-definisi yang digunakan dalam penelitian ini. Data yang diperoleh kemudian dianalisis secara deskriptif-kualitatif.

${ }^{7}$ Lihat lebih lanjut dalam Soerjono Soekanto dan Sri Mamudji, Penelitian Hukum Normatif: Suatu Tinjauan Singkat, Cet. XIV, Rajawali Pers, Jakarta, 2014, hlm. 13. 


\section{Hasil Penelitian dan Pembahasan}

\section{Eksistensi Negeri Ambon dan Nagari Sumatera Barat sebagai Desa Adat dalam Tinjauan Undang-undang Desa}

Desa adat telah diatur dalam Undang-Undang Desa dalam Pasal 1 ayat (1) yaitu:

"Desa adalah desa dan desa adat atau yang disebut dengan nama lain, selanjutnya disebut Desa, adalah kesatuan masyarakat hukum yang memiliki batas wilayah yang berwenang untuk mengatur dan mengurus urusan pemerintahan, kepentingan masyarakat setempat berdasarkan prakarsa masyarakat, hak asal usul, dan/atau hak tradisional yang diakui dan dihormati dalam sistem pemerintahan Negara Kesatuan Republik Indonesia".

Pasal tersebut mengatur bahwa Desa sebagai subyek hukum yang mengelola kepentingan masyarakat setempat sekaligus mengatur urusan atau kewenangan pemerintahan, seperti halnya daerah. Desa diakui sebagai kesatuan masyarakat hukum berdasarkan asal-usul dan adat-istiadat (self governing community) sekaligus disiapkan sebagai entitas otonom sebagai local self government. Undang-Undang Desa juga mengatur mengenai konsep optional village untuk mengakomodasi dan melembagakan keragaman Desa yang ada di seluruh wilayah di Indonesia.

Pengaturan mengenai Desa Adat terdapat dalam Bab XIII Pasal 96 sampai dengan Pasal 110 Undang-Undang Desa. Desa adat yang diakui dalam UndangUndang Desa harus memenuhi syarat-syarat tertentu untuk dapat diakui sebagai Desa Adat yaitu:

a. kesatuan masyarakat hukum adat beserta hak tradisionalnya secara nyata masih hidup, baik yang bersifat teritorial, genealogis, maupun yang bersifat fungsional;

b. kesatuan masyarakat hukum adat beserta hak tradisionalnya dipandang sesuai dengan perkembangan masyarakat; dan

c. kesatuan masyarakat hukum adat beserta hak tradisionalnya sesuai dengan prinsip Negara Kesatuan Republik Indonesia.

Berdasarkan Undang-Undang Desa tersebut maka dapat dinyatakan bahwa desa adat telah diakomodasi eksistensinya dalam bentuk dan nama apapun, selama merupakan kesatuan masyarakat hukum yang memiliki batas wilayah yang berwenang untuk mengatur dan mengurus urusan pemerintahan, 
kepentingan masyarakat setempat, begitu juga Nagari-nagari di Sumatera Barat dan Negeri-negeri di kota Ambon.

Negeri Ambon dengan berbagai strukturnya masih eksis hingga saat ini sebagai desa adat. Negeri ini telah memenuhi persyaratan di atas, yaitu memiliki teritorial dan geneologis serta fungsionalnya. Di negeri Ambon ini tentu saja memiliki teritorialnya, dan terdapat fam-fam secara geneologis di sana. Negeri memiliki strukturnya yang tetap eksis seperti adanya Raja, Saniri Negeri, dan Soa yang terdiri dari fam-fam atau marga. ${ }^{8}$ Semua berjalan secara fungsional dalam masyarakat. Sehingga persyaratan dalam Undang-Undang Desa tersebut mesti sudah terpenuhi pula.

Begitu juga Nagari di Sumatera Barat telah ada sejak masa sebelum kemerdekaan. Pada masa setelah kemerdekaan, Nagari tetap ada, berdasarkan SK Gubernur 155-156, 1974 pada masa Orde Lama. Setelah diberlakukan UU Desa 1979 Nagari mulai menghilang dan berganti menjadi Desa, di mana Jorong-jorong yang di bawah wilayah Nagari diubah menjadi Desa. ${ }^{9}$

Di era pasca Orde Baru dengan adanya otonomi daerah, semangat "Kembali Ke Nagari" kiat gencar didengungkan. Akhirnya Nagari diaktifkan kembali. Berdasarkan UU Desa yang menyebutkan nomenklatur desa dengan varian "Desa adat atau yang disebut dengan nama lain" Nagari termasuk kategori Desa yaitu Desa adat. Nagari ini dapat diakomodasi sebagai Desa berdasarkan UU Desa tersebut. Hal ini sebagaimana tertera dalam Pasal 1 Undang-Undang Desa di atas.

Begitu juga dalam persyaratan sebagai Desa adat yang tercantum di Pasal 96 dan 110 Undang-Undang Desa tersebut di atas, Nagari di Sumatera Barat juga telah memenuhinya. Misalnya nagari sebagai desa adat yang memiliki teritoral dan geneologis serta fungsi dan struktur yang berjalan di masyarakat. Masyarakat Sumatera Barat Minangkabau terdiri dari berbagai suku dan klan yang tergabung

${ }^{8}$ Hasil observasi penulis dan hasil wawancara dengan ketua Saniri negeri Batu Merah, di Balai negeri Batu Merah 18 Agustus 2018.

${ }^{9}$ Hasil Wawancara dengan Bapak Ilhandi Taufiq Dosen Hukum Tatanegara Fakultas Hukum Universitas Andalas Padang, yang juga sebagai tokoh masyarakat di Padang, di Yogyakarta, 18 September 2018. 
dalam nagari-nagari. Nagari juga memiliki struktur yang fungsional seperti wali nagari, Kerapatan Adat Nagari (KAN) dan Badan Musyawarah Nagarinya. ${ }^{10}$

Penetapan Desa Adat dengan peraturan daerah setingkat Kabupaten atau Kota yang merupakan wilayah administratif Desa Adat tersebut. Pembentukan Desa Adat setelah penetapan Desa Adat melalui Peraturan Daerah tersebut dilakukan dengan memperhatikan faktor penyelenggaraan Pemerintahan Desa, pelaksanaan pembangunan Desa, pembinaan kemasyarakatan Desa, serta pemberdayaan masyarakat Desa dan sarana prasarana pendukung. Desa Adat yang telah diakui keberadaannya dengan adanya penetapan tersebut memilik kewenangan berdasarkan hak asal-usul yang memperhatikan prinsip keberagaman, meliputi: ${ }^{11}$

a. pengaturan dan pelaksanaan pemerintahan berdasarkan susunan asli;

b. pengaturan dan pengurusan ulayat atau wilayah adat

c. pelestarian nilai sosial budaya Desa Adat;

d. penyelesaian sengketa adat berdasarkan hukum adat yang berlaku di Desa Adat dalam wilayah yang selaras dengan prinsip hak asasi manusia dengan mengutamakan penyelesaian secara musyawarah;

e. penyelenggaraan sidang perdamaian peradilan Desa Adat sesuai dengan ketentuan peraturan perundang-undangan;

f. pemeliharaan ketenteraman dan ketertiban masyarakat Desa Adat berdasarkan hukum adat yang berlaku di Desa Adat; dan

g. pengembangan kehidupan hukum adat sesuai dengan kondisi sosial budaya masyarakat Desa Adat.

h. pelaksana penugasan dari Pemerintah dan/atau Pemerintah Daerah kepada Desa Adat meliputi penyelenggaraan Pemerintahan Desa Adat, pelaksanaan Pembangunan Desa Adat, pembinaan kemasyarakatan Desa Adat, dan pemberdayaan masyarakat Desa Adat

i. menyelenggarakan fungsi permusyawaratan dan Musyawarah Desa Adat sesuai dengan susunan asli Desa Adat atau dibentuk baru sesuai dengan prakarsa masyarakat Desa Adat.

Di wilayah Ambon, terdapat Negeri-negeri sebagai Desa adat. Pengunaan nama Negeri dengan segala nama lembaga aparatnya untuk menyebut Desa ini dapat diakomodasi dalam Pasal 1 Undang-Undang Desa, sehingga Negeri seperti juga desa memperoleh hak dan wewenang yang relatif sama. Bahkan Negeri di Ambon sebagai desa adat memiliki kewenangan lebih terkait dengan penerapan

\footnotetext{
${ }^{10}$ Hasil observasi penulis di Sumatera Barat dan hasil wawancara dengan Datuak Asa Basa (Hasan Basri), Ketua KAN Kecamatan Mandiangin Kota Bukittinggi di kediamannya 23 Oktober 2018.

11 Pasal 1 Undang-Undang Nomor 6 Tahun 2014 tentang Desa
} 
dan penegakan hukum adat setempat. Diantara kewenangan tersebut berdasarkan hak asal usul yang memperhatikan prinsip keberagaman.

Nagari dalam hal ini juga tetap dengan nama-nama struktur atau susunan aslinya yaitu adanya Raja, Saniri Nagari, Soa dan Fam-Fam juga Kewang dan Marinyo. Semua struktur atau susun asli tersebut tetap berjalan sebagaimana fungsi awalnya. Terkait dengan perselisihan dan permasalahan adat, desa adat juga berhak menyelesaikannya. Dalam konteks Negeri Ambon ini, Saniri Negeri lah yang menyelesaikan persoalan dan perselisihan terkait dengan hukum adat setempat. Begitu juga terkait dengan tanah-tanah adat yang disebut dengan hak ulayat. Negeri lah yang berhak atas pengelolaan tanah ulayat tersebut. ${ }^{12}$

Di seluruh wilayah Sumatera Barat, dalam kabupaten Desa disebut dengan Nagari, sedangkan di wilayah kota disebut dengan kelurahan. Pengunaan nama Nagari dengan segala nama lembaga aparatnya untuk menyebut Desa ini dapat diakomodasi dalam Pasal 1 Undang-Undang Desa, sehingga Nagari seperti juga desa memperoleh hak dan wewenang yang relatif sama. Bahkan nagari di Minang kabau memiliki kewenangan lebih terkait dengan penerapan dan penegakan hukum adat setempat.

Desa Adat yang telah diakui keberadaannya dengan adanya aturan tersebut memiliki kewenangan berdasarkan hak asal usul yang memperhatikan prinsip keberagaman, sebagaimana tersebut di atas. Oleh karena itu, Nagari juga tetap dengan nama-nama struktur atau susunan aslinya yaitu adanya wali nagari, Kerapatan adat nagari dan badan musyawarah nagari, yang tidak dimiliki oleh desa-desa pada umumnya. Begitu juga hak untuk menguasai tanah ulayat, hak untuk mengembangkan adat dan budayanya serta hak untuk penyelesaian persoalan brdasarkan hukum adat setempat. Yang terakhir ini merupakan wilayah kerapatan adat nagari, sebagai badan yudikatif nagari. Terutama untuk persoalan tanah, Kerapatan Adat Nagari (KAN) ini banyak menyelesaikan perselisihan diantara warga nagari. ${ }^{13}$

\footnotetext{
12 Hasil Observasi dan Wawancara penelitian Lapangan di Ambon.

${ }_{13}$ Hasil Observasi penulis di Sumatera Barat dan Hasil wawancara dengan Datuak Asa Basa (Hasan Basri), Ketua KAN Kecamatan Mandiangin Kota Bukittinggi di kediamannya 23 Oktober 2018.
} 
KAN menyelenggarakan persidangan untuk menyelesaian perkara adat diantara warganya. Terutama terkait tanah dan waris, penerbitan sertifikat tanah, BPN (Badan Pertanahan Nasional) tidak akan mau menerbitkan sertifikat tanah kecuali sudah ada persetujuan dan tanda tagan dari KAN. Karena KAN ini yang terlebih dahulu harus menyelesaian perkara sengketa tanah antar warga. ${ }^{14}$

Adapun nagari ini keluasannya berbeda-beda, dan banyak yang terlalu luas lebih dari keluasan desa di wilayah di luar Sumatera Barat. Karena pada dasarnya, Nagari dahulu minimal harus terdiri dari empat suku. Terdapat nagari yang terlalu luas, misalnya terdapat satu kecamatan di wilayah Kabupaten Pasaman Barat yang hanya terdiri dari satu Nagari. Sehingga, Nagari seperti ini sangat luas wilayahnya dan harus mengurus warga yang sangat banyak dbandingkan dengan untuk nagari yang lebih sempit atau ukuran Desa di Jawa misalnya. Sehingga beberapa Nagari merancang adanya pemekaran menjadi beberapa Nagari. Terdapat Nagari yang telah melakukan pemekaran misalnya Nagari Ampang yang teletak di Kabupaten Pesisir Selatan pecah menjadi Nagari Ampang dan Nagari Pulau karang. ${ }^{15}$

Biasanya luas wilayah nagari 4 atau 5 kali lipat lebih luas daripada luas Desa di luar wilayah Sumatra Barat. ${ }^{16}$ Jika dahulu di masa Orde Baru Jorong menjadi Desa, maka Nagari yang terdiri dari beberapa Jorong kini menjadi identik dengan satu Desa. Sehingga dalam perkembangannya beberapa Nagari melakukan pemekaran. ${ }^{17}$ Begitu juga di daerah-daerah lainnya. Sehingga jumlah Nagari cenderung semakin bertambah.

\footnotetext{
${ }^{14}$ Hasil wawancara dengan Datuak Asa Basa (Hasan Basri), Ketua KAN Kecamatan Mandiangin Kota Bukittinggi di kediamannya 23 Oktober 2018.

${ }^{15}$ Hasil wawancara dengan Bapak Zuarlis Saleh, pensiunan Hakim Peradilan Agama Padang, tokoh masyarakat di Padang di kediamannya 24 Oktober 2018.

${ }^{16}$ Boy Yendra Tamin "Nagari di Sumatera Barat Sebagai Wilayah Pemerintahan Terendah dan Perkembangannya"

17 Hasil wawancara dengan Bapak Zuarlis Saleh, seorang Datuk dari Kecamatan Mandiangin Kota Bukittinggi di kediamannya 22 Oktober 2018.
} 


\section{Negeri Ambon dan Nagari Sumatera Barat dalam Tinjauan Sistem Ketatanegaraan Modern}

Sistem ketatanegaraan modern mengenal pembagian kekuasaan atau bahkan pemisahan kekuasaan antara badan legislatif, eksekutif dan yudikatif. ${ }^{18}$ Dalam desa adat ini pun juga memiliki badan-badan serupa ini. Negeri di Kota Ambon dipimpin oleh seorang raja, sebagai kepala pemerintahan atau kepala eksekutifnya. Raja dibantu oleh para tetua adat. Lembaga lain yaitu saniri negeri sebagai lembaga legislatifnya. Adapun penyelesaian perkara adat juga berada di tetua-tetua adat yang tergabung dalam saniri negeri dan dipimpin oleh Raja. ${ }^{19}$ Sehingga di sini kekuasaan yudikatif dalam desa adat negeri ini menjadi kurang tegas pemisahannya.

Dari paparan tersebut, maka dapat diketahui bahwa dalam susunan asli desa adat pada negeri Ambon ada kekuasaan eksekutif pada Raja, dan legislatif pada saniri negeri dan yudikatif pada tetua-tetua adat, yang tergabung baik dalam saniri negeri maupun di bawah Raja.

Adapun Nagari di Sumatera Barat dipimpin oleh seorang wali nagari. Pada masa sebelum reformasi, terdapat beberapa lembaga dalam nagari, yaitu ada Kerapatan Adat Nagari (KAN) dan Kerapatan Nagari (KN). KAN merupakan lembaga adat dalam masyarakat dan lembaga yudikatif untuk memutuskan sengketa adat. Adapun KN merupakan lembaga legislatif, eksekutif dan yudikatif. Kepala KN adalah wali nagari. ${ }^{20} \mathrm{Hal}$ ini berlaku sejak diatur dalam UU Nomor 5 Tahun 1979 hingga UU Nomor 32 Tahun 2004.

Setelah berlakunya UU Nomor 32 Tahun 2004, KAN tetap menjadi lembaga adat dan yudisial di samping ada Badan Perwakilan Nagari (BPN) atau di beberapa nagari disebut Badan Permusyawaratan (Bamus) Nagari sebagai perwakilan legislatif. Sehingga pembagiannya adalah bahwa KAN sebagai

18 Teori Trias Politika Montesque yang membagi kekuasaan negara menjadi legislatif, eksekutif dan yudikatif. Hal ini sebagaimana dimuat dalam berbagai buku tata negara ataupun ilmu politik, diantaranya Zainal Arifin Mochtar, Lembaga Negara Independen: Dinamika Perkembangan dan Urgensi Penataannya Kembali Psca Amandemen Konstitusi, Raja Grafindo Persada, Jakarta, 2016, hlm. 1.

${ }^{19}$ Hasil wawancara dengan Bapak Haji Latua Tokoh masyarakat di Kota Ambon, 18 Agustus 2018.

${ }^{20}$ Hasil Wawancara dengan Bapak Ilhandi Taufiq Dosen Hukum Tatanegara Fakultas Hukum Universitas Andalas Padang, yang juga sebagai tokoh masyarakat di Padang, di Yogyakarta, 18 September 2018. 
lembaga yudikatif, BPN atau bamus sebagai lembaga legislatif dan wali nagari sebagai eksekutif. ${ }^{21}$

Selain masalah pembagian kekuasaan sebagaimana dipaparkan di atas, sistem pemilihan pemimpin juga menjadi penting dalam aturan ketatanegaraan. Misalnya, selama ini dikenal dengan adanya sistem pemilihan langsung atau sistem perkawilan, yang kemudian disebut dengan demokrasi langsung atau perwakilan.

Negeri-negeri di Ambon dipimpin oleh seorang raja. Layaknya sebuah kerajaan pada era monarkhi, raja merupakan penguasa kerajaan yang ditetapkan secara turun menurun dari keluarga atau keturunan raja sebelumnya. Negeri di ambon di era modern Indonesia pasca reformasi ini, raja dipilih melalui pemilihan umum, seperti pemilihan kepala desa di Jawa. ${ }^{22}$ Sehingga perpaduan adat dan sistem pemilihan modern pun terjadi dalam pemilihan raja negeri Ambon ini.

Mekanisme pemilihan raja negeri awalnya di saniri negeri. Hanya keluarga dan keturunan raja saja yang bisa mencalonkan diri menjadi raja negeri. Saniri negeri akan menetapkan beberapa calon yang ada, untuk maju ke pemilihan umum yang diikuti seluruh pemilih yaitu warga negeri. Calon Raja yang terpilih adalah yang mendapatkan suara terbanyak. Kemudian ditetapkan oleh saniri negeri, dan ditetapkan dengan Keputusan Bupati setempat (SK Bupati). ${ }^{23}$

Inilah model pemilihan yang merupakan perpaduan antara adat dan sistem pemilihan modern dalam ketatanegaraan Indonesia. Adat atau tradisi bahwa Raja adalah turun-temurun dari keturunan raja tetap tetap berjalan. Raja yang ditetapkan oleh saniri negeri tetap berjalan. Namun, sistem pemilihan dan penetapan dengan SK Bupati juga tetap dilaksanakan.

Adapun Nagari di Sumatera Barat, dipimpin oleh seorang wali nagari. Wali nagari dipilih oleh seluruh warga nagari atau istilahnya anak nagari. Pada dasarnya dalam adat minangkabau penyelesaian perkara selalu dilaksanakan dengan musyawarah mufakat. Begitu juga pemilihan datuk, pemilihan anggota

${ }^{21}$ Hasil Wawancara dengan Bapak Ilhandi Taufiq Dosen Hukum Tatanegara Fakultas Hukum Universitas Andalas Padang, yang juga sebagai tokoh masyarakat di Padang, di Yogyakarta, 18 September 2018.

${ }^{22}$ Hasil wawancara dengan Saniri Negeri Batu Merah, pada 18 Agustus 2018.

${ }^{23}$ Hasil wawancara dengan Haji Latua, tokoh masyarakat kota Ambon 19 Agustus 2018. 
Kerapatan adat nagari dan pemilihan wali nagari. Seperti juga di Ambon, di nagari Sumatera Barat ini juga terjadi perpaduan antara model adat dan sistem pemilihan modern dengan pemungutan suara.

Mekanisme pemilihan wali nagari yaitu sebagai berikut:24 1) Bakal calon dipilih dan diseleksi oleh dan dalam Kerapatan Nagari berdasarkan kelayakannya; 2) Forum KAN ini dilaksanakan dengan musyawarah mufakat; 3) Dari para bakal calon akan dipilih dan kemudian ditetapkan sebagai calon wali nagari, yang selanjutnya maju dalam pemilihan umum wali nagari; 4) Pemungutan suara dalam rangka pemilihan wali nagari; 5) Pemungutan suara dilakukan oleh semua anak nagari yang telah memenuhi syarat untuk memilih yaitu cakap hukum; 6) Calon yang mendapatkan suara terbanyak adalah yang menang dan selanjutnya ditetapkan sebagai wali nagari.

Seorang wali nagari harus memiliki banyak pengetahuan tentang hukum adat setempat. Sehingga tidak sembarangan orang dapat mencalonkan diri sebagai wali nagari. Disinilah peran KAN dalam malakukan seleksi dan menetapkan calon wali nagari. Sehingga tetap ada peran adat dalam pemiihan wali nagari ini, yang dapat dikatakan sebagai perpaduan antara sistem pemilihan adat dan sistem pemiihan modern dalam ketatanegaraan Indonesia yaitu dengan pemilihan suara.

Perjuangan masyarakat Maluku untuk menghidupkan kembali tatanan adat beserta kelembagaan adat yang pernah ada dalam kehidupan masyarakat Maluku merupakan suatu perjuangan yang sesungguhnya terpendam ketika berkuasanya pemerintahan orde baru. Baru setelah penetapan Undang-Undang Nomor 32 Tahun 2004, masyarakat Maluku melakukan suatu gerakan bersama untuk menegakkan eksistensi identitas masyarakat adat Maluku sebagai suatu persekutuan masyarakat hukum adat yang harus diakui oleh Negara Republik Indonesia, tak terkecuali di Ambon. Begitu juga dengan berlakunya UndangUndang Desa yang mengakomodasi Desa adat dengan segala strukturnya.

Pencantuman kata "Negeri" sebagai suatu bentuk persekutuan masyarakat hukum adat yang ada di Ambon sebagaimana telah dilakukan dalam Undang-

${ }^{24}$ Hasil wawancara dengan Datuak Asa Basa (hasan Basri), Ketua KAN Kecamatan Mandiangin Kota Bukittinggi 23 Oktober 2018. 
Undang Nomor 32 Tahun 2004 tentang Pemerintahan Daerah sebagai koreksi dari Undang-Undang Nomor 22 Tahun 1999 tentang Pemerintahan Daerah merupakan bentuk pengakuan Negara terhadap eksistensi masyarakat adat di Ambon berupa negeri.

Adapun pengakuan Negara terhadap persekutuan masyarakat adat yang ada di Ambon sebagaimana tercantum dalam penjelasan atas Pasal 202 ayat (1) telah membuka ruang untuk bangkitnya kembali lembaga-lembaga adat. Hal ini didasarkan Perda Provinsi Maluku Nomor 14 Tahun 2005 tentang Penetapan Kembali Negeri sebagai Kesatuan Masyarakat Hukum Adat Dalam Wilayah Pemerintahan Provinsi Maluku. Aturan ini merupakan turunan dari UndangUndang Pemerintahan Daerah saat itu, yang dijabarkan lagi lebih detail dalam perda masing-masing daerah.

Kemudian yang menjadi persoalan selanjutnya adalah bagaimana Perda tersebut ditindaklanjuti hingga pada tingkat desa atau yang disebut dalam Perda Kota Ambon Nomor 3 Tahun 2008 dengan sebutan "Peraturan Negeri". Diharapkan dalam Perneg tersebut dapat dijabarkan lebih jauh mengenai kedudukan formal masing-masing lembaga yang ada dalam struktur pemerintahan negeri termasuk saniri, yang sebelumnya hanya mendapatkan pengakuan secara sepihak oleh masyarakatnya saja sehingga pada akhirnya juga dapat diwujudkan menjadi suatu tatanan hukum yang diakui oleh negara juga secara formal. Sebagai implikasinya, kedudukan formal dari saniri yang belum ada. Hal ini juga telah menyebabkan ketimpangan di dalam pelaksanaan peran saniri sebagai lembaga adat yang berkompeten dalam suatu masyarakat adat. Jika ada suatu persoalan yang diselesaikan oleh saniri, tetapi kurang dukungan yang maksimal dari lembaga yang memperoleh kedudukan formal yang jelas seperti kepolisian. ${ }^{25}$

Pemberlakuan mekanisme adat dalam penyelesaian persoalan yang ada dalam masyarakat dengan sendirinya telah menimbulkan suatu perubahan sikap dari masing-masing pihak. Di satu sisi, saniri seperti memperoleh kekuatan hukum dalam menjalankan kedudukannya sebagai pimpinan-pimpinan

${ }^{25}$ Ronald Alfredo, "Lembaga Adat "Saniri” Sebagai Forum Komunikasi Dalam Penyelesaian Masalah Publik Di Ambon: Traditional Institution "Saniri" as Communication Forum In Solving Public Issues In Ambon", Jurnal Komunikasi KAREBA No. 3 Vol. 1 Juli - September 2011, hlm. 338 
masyarakat yang sudah sekian lama ini tidak pernah dilakoni, sehingga terdapat perilaku para anggota saniri yang terkadang dinilai berlebihan oleh pihak kepolisian.

Pada masa lampau lembaga adat memiliki legitimasi secara adat untuk melakukan upaya penyelesaian persoalan-persoalan yang ada dalam masyarakatnya, namun pada saat ini telah ada begitu banyak perubahanperubahan yang berlangsung dalam masyarakat. Penyesuaian peran dari masingmasing lembaga baik lembaga formal maupun lembaga adat merupakan tanggung jawab pemerintah untuk menciptakan suatu kerjasama yang terpadu antara lembaga formal dan lembaga adat dalam suatu mekanisme yang solid demi ketentraman kehidupan masyarakat. ${ }^{26}$

Dari paparan tersebut di atas, dapat dilihat adanya pergulatan antara adat dan modernitas. Misalnya bagaimana eksistensi masyarakat adat dengan segala struktur dan perannya yang asli harus mendapatkan legitimasi dari peraturan hukum negara dalam bentuk legislasi dan hukum tertulis. Kemudian peran saniri sebagai lembaga yudikatif adat yang menyelesaikan masalah-masalah adat juga dianggap relatif berseberangan dengan peran kepolisian, karena adanya wilayah hukum adat dan hukum nasional Indonesia saat ini. Sehingga eksistensi masyarakat adat dan desa adat dengan susunan asli dan perannya ini relatif rumit dilaksanakan.

Saniri Negeri menurut prinsip adat merupakan jantung dari kesatuan masyarakat adat suatu negeri, karena saniri negeri memiliki keterkaitan yang utuh dengan seluruh masyarakat negeri. Saniri Negeri merupakan inspirasi yang timbul dari masyarakat Ambon sendiri yang diwujudkan untuk menciptakan keteraturan dan keseimbangan dalam kehidupan masyarakat itu sendiri. Sementara itu, Nagari di Sumatera Barat yang telah eksis sejak sebelum kemerdekaan Indonesia, merupakan kesatuan masyarakat adat yang terdiri dari beberapa suku dan klan. Model masyarakat adat ini berjalan dengan musyawarah dan mufakat warga dan para tetua adat, datuak dan para cerdik pandai. Nagari berjalan dengan kepemimpinan kolektif para datuak dan tetua-tetua adat serta 
cerdik pandai tersebut. Dalam perkembangannya terjadi perubahan-perubahan konsep desa dan nagari ini. Pada masa orde baru nagari tereliminasi berubah menjadi desa-desa untuk wilayah jorong (wilayah di bawah nagari). ${ }^{27}$

Desa-desa bertransformasi menjadi nagari setelah masa orde baru usai. Permasalahan yang timbul kemudian, bentuk nagari seperti apa yang akan diterapkan kembali, apakah nagari asli dengan bentuk kepemimpinan kolektif ataukah nagari sebelum diterapkannya UU No. 5 Tahun 1979 yaitu nagari berada di bawah pimpinan wali nagari. Sebagian orang membayangkan bahwa kembali ke nagari berarti kembali ke pemerintahan adat atau mengembalikan nilai-nilai budaya dan adat Minangkabau. Pikiran ini tumbuh subur di kalangan rakyat dan pemangku adat serta sebagian akademisi. Sementara dari kalangan legislator dan pemerintahan daerah mengembangkan cara pandang yang lain. Pemerintahan nagari yang akan dihidupkan adalah yang bisa menjawab tantangan sekaligus modern. Sebuah nagari yang merupakan perpaduan antara kelembagaan tradisional dan organisasi modern. ${ }^{28}$

Nagari dikatakan bersifat istimewa dengan alasan antara lain: Pertama, sebelum ada negara, nagari sudah tersusun menurut asal-asul dan susunan aslinya tetapi tentram dan makmur; Kedua, anak nagari menganut sistem kekerabatan matrilinial; Ketiga, landasan kemasyarakatannya adalah adat basandi syara', syara' basandi kitabullah; Keempat, adanya hukum adat yang mengatur kehidupan masyarakat; Kelima, pemimpinnya yang disebut ninik mamak pemangku adat. Keenam, wilayah adatnya yang disebut tanah ulayat; Ketujuh, rakyatnya yang setia dengan Pancasila, UUD 1945, dan NKRI. Dari tujuh alasan itu tidak ada alasan pemerintah pusat tidak mau memberikan nagari bersifat istimewa. ${ }^{29}$

Muhammad Yamin pernah berpidato di parlemen pada 1957 dalam rapat dengar pendapat dengan pemerintah Kabinet Sastroamijoyo ke-II yang berjudul "Dewan Banteng Contra Neo Ningrat", mengatakan bahwa kepemimpinan nagari akan kontra dengan kepemimpinan Neo Ningrat yang ada di desa dan

\footnotetext{
${ }^{27}$ Hasil wawancara dengan Datuak Parmato di Jln Irigasi Bukittinggi 22 Oktober 2018.

${ }^{28}$ Ronald Alfredo, "Lembaga Adat..." Op. Cit.,, hlm. 338

${ }^{29}$ Ibid.
} 
lurah. Minangkabau identik dengan nagari, sedangkan jawa identik dengan lurah dan desa. ${ }^{30}$

Pemerintahan desa yang bercorak nasional mengakibatkan institusi-institusi lokal menjadi terpinggirkan. Pada masa ini kelompok individu menggeser dominasi kelompok genealogis dalam pemerintahan desa. Seiring dengan bergulirnya reformasi dan diimplementasikannya kebijakan desentralisasi berdasarkan UU No. 22/1999, Pemerintah Daerah Sumatera Barat memutuskan untuk kembali menghidupkan pemerintahan nagari. Sekarang dilanjutkan dan dikuatkan dengan Undang-Undang Desa yang lebih mengakomodasi adanya Desa adat dengan struktur aslinya. Nagari sekarang berbeda dengan nagari yang dulu (sebelum dikeluarkannya UU No. 5/1979). ${ }^{31}$

Pemerintah berusaha untuk memadukan organisasi modern dengan institusi tradisional dalam pemerintahan nagari saat ini, artinya ada upaya untuk menyinergikan kebijakan pemerintah dan aksi sosial berdasarkan adat istiadat ditingkat nagari. Untuk mewujudkan sinergi tersebut, pemerintah mengeluarkan berbagai regulasi yang mengatur pembentukan lembaga-lembaga dalam nagari. Lembaga-lembaga ini diharapkan dapat menjadi wadah yang menampung partisipasi masyarakat dalam membangun nagari. Dalam kenyataannya, lembaga-lembaga tersebut justru tidak bekerja optimal, bahkan saling tumpang tindih. ${ }^{32}$

Pengakuan kembali nagari sebagai pemerintahan terendah melalui otonomi daerah, justru menempatkan nagari pada kondisi yang dilematis. Nagari menerima intervensi pemerintah yang menempatkan nagari sebagai bagian dari birokrasi negara. Di sisi lain proses ini mengurangi otonomi nagari karena membuat nagari secara substansial terbentuk desa, dan mengurangi ciri utama dari pemerintahan nagari format lama, atau tradisi masyarakat Minang yaitu "kepemimpinan kolektif". Selain itu keinginan pemerintah untuk menyinergikan kelembagaan lokal dengan organisasi modern, di lapangan justru menimbulkan berbagai potensi konflik. Jika hal ini tidak dikelola dengan baik, maka akan 
menjadi hambatan dalam mewujudkan nagari yang otonom karena konflik dapat melemahkan pemerintahan nagari (negatif fungsional). ${ }^{33}$

Satu hal lagi yang hilang yaitu musyawarah mufakat tergantikan dengan pemungutan suara. Masyarakat adat yang memutuskan sesuatu dengan menggunakan musyawarah mufakat, bahkan dalam pemilihan Datuk, pemilihan wali nagari, kini tergantikan dengan vooting atau pemilihan atau pemungutan suara. ${ }^{34}$

\section{Penutup}

Penelitian ini kemudian berkesimpulan bahwa: pertama, setelah berlakunya Undang-Undang Desa yang mengakomodasi Desa adat dan nama lainnya, maka Negeri di Ambon dan nagari Sumatera Barat mulai mendapatkan hak-haknya sebagai desa adat dengan keistimewaannya yaitu hak susunan asli dan asalusulnya. Sehingga desa adat ini tetap menggunakan nama dan susunan asli sebagaimana adanya mereka seperti negeri Ambon memiliki Raja, Saniri Negeri, Soa dan Fam, Kewang dan Marinyo. Sedangkan Nagari Sumatera Barat memiliki Wali nagari, Kerapatan adat Nagarai (KAN), dan Badan permusyawaratan Nagari (Bamus). Masing-masing menjalankan fungsinya sebagaimana hak dan kewenangannya terhadap asal-usul dan susunan asli desa adat.

Kedua, dalam sistem demokrasi modern, desa adat ini banyak mengalami pergeseran karena adaptasi dengan sistem demokrasi modern. Peran-peran lembaga desa adat masih tetap sebagaimana asal-usul atau susunan aslinya. Misalnya, di negeri terdapat Raja sebagai kepala eksekutif dan Saniri negeri sebagai legislatifnya. Sementara di dalam Nagari terdapat Wali nagari sebagai kepala pemerintahan eksekutif dan Bamus sebagai legislatifnya serta KAN sebagai lembaga yudikatif yang menyelesaikan masalah dan konflik adat antar warganya. Di sisi lain pergeseran nilai adat meunju adaptasi nilai demokrasi modern juga terjadi. Misalnya Raja di negeri-negeri Ambon yang bersifat turuntemurun dan ditetapkan oleh Saniri nagari sekarang harus melalui pemungutan suara pemilihan langsung. Begitu juga pemilihan wali nagari, yang dahulu berdasarkan musyawarah mufakat dalam forum nagari yang dihadiri para

\footnotetext{
${ }^{33}$ Ibid.

${ }^{34}$ Hasil wawancara dengan Datuak Parmato di Bukit Tinggi, 22 Oktober 2018.
} 
anggota KAN dan para datuak, sekarang harus melalui pemungutan suara dalam pemilihan langsung juga. Di sisi lain, juga terjadi pergeseran nilai kepemimpinan kolektif di nagari Sumatera barat menjadi model desa jawa yang feodal dan intsruksional. Begitu juga peran-peran lembaga adat dalam penyelesaian sengketa juga terdistorsi adanya sistem hukum nasional Indonesia. Nagari sebagai kesatuan klan dan atau suku, kini nagari hanya kesatuan wilayah administratif semata.

Penelitian ini menyarankan agar diwujudkan kompromi dan adaptasi yang baik antara nilai-nilai adat dalam desa adat dengan struktur asalnya dan sistem tata pemerintahan modern Indonesia saat ini. Lembaga adat dan lembaga pemerintah formal dapat bekerjasama dan saling konfirmasi dalam menyelesaikan persoalan dalam masyarakat. Nilai-nilai adat yang ada juga hendaknya diteruskan kepada para generasi baru yang lahir dalam kondisi modernitas, sehingga nilai-nilai adat akan tetap berlangsung walaupun beberapa harus diadaptasi dengan nilai modern.

\section{Daftar Pustaka}

\section{Buku}

Alisjahbana, S. Takdir, Perkembangan Sejarah Kebudayaan Indonesia Dilihat dari Jurusan Nilai-Nilai, Yayasan Idayu, Jakarta, 1977.

Effendi, Ziwar, Hukum Adat Ambon-Lease, Pradnya Paramita, Jakarta, 1987.

Mochtar, Zainal Arifin, Lembaga Negara Independen: Dinamika Perkembangan dan Urgensi Penataannya Kembali Psca Amandemen Konstitusi, Raja Grafindo Persada, Jakarta, 2016.

Soerjono Soekanto dan Sri Mamudji, Penelitian Hukum Normatif: Suatu Tinjauan Singkat, Cet. XIV, Rajawali Pers, Jakarta, 2014.

Sudiyat, Iman, Asas-Asas Hukum Adat Bekal Pengantar, cet. ke-2,: Liberty, Yogyakarta, 1991.

Sumarsono, Sistem Pemerintahan Tradisional Daerah Ambon, Departemen Pendidikan dan Kebudayaan, Jakarta, 1993.

Waileruny, Samuel, Membongkar Konspirasi di Balik Konflik Maluku, Yayasan Pustaka Obor Indonesia, Jakarta, 2010.

\section{Jurnal}

Aulia Rahmat, "Civil Society Nagari Minangkabau: Restrukturisasi Adat dalam Lintasan Kebijakan", Jurnal Sejarah, Kebudayaan dan Kependidikan Vol 8, No 
sumbar.ac.id/index.php/bakaba/article/view/4300

Ronald Alfredo, "Lembaga Adat "Saniri" Sebagai Forum Komunikasi Dalam Penyelesaian Masalah Publik Di Ambon", Jurnal Komunikasi KAREBA No. 3 Vol. 1 Juli - September 2011.

Susi Fitria Dewi, "Konflik dalam Pemerintahan Nagari: Penelitian di Nagari Padang Sibusuk Kabupaten Sawahlunto Sijunjung Sumatera Barat" ejournal UNP Vol. 5 No. 1 Tahun 2006.

W. Azwar, Yunus, Y., Muliono, M., \& Permatasari, Y., “Nagari Minangkabau: The Study of Indigenous Institutions in West Sumatra, Indonesia", Jurnal Bina Praja: Journal of Home Affairs Governance, 10 (2), 2018, https:// doi.org/10.21787/jbp.10.2018.231-239

Yustina Trihoni Nalesti Dewi and Kwik, Jonathan and Watloly, Aholiab, "The Strategic Role of Lembaga Adat Negeri in the Fulfilment of Victims' Rights to Reparation in Post-Conflict Ambon", Udayana Journal of Law and Culture, 1 (2), 2017.

ISSN

2549-0680;

https://ojs.unud.ac.id/index.php/UJLC/article/view

\section{Laporan Penelitian}

Dewi, Yustina Trihoni Nalesti and Pandiangan, Andreas and Suroto, Valentinus, Revitalisasi Lembaga Adat "Saniri" Sebagai Aktualisasi Otonomi Desa Dalam Rekonsiliasi Pasca Konflik Di Ambon, Project Report, Semarang, 2020, dalam http://repository.unika.ac.id/23629/

\section{Tugas Akhir}

Mardeli, Iis, "Kedudukan Desa dalam Sistem Ketatanegaraan Republik Indonesia", Tesis, Magister Ilmu Hukum Universitas Atma Jaya Yogyakarta, 2015.

\section{Internet}

Setoro Eko, "Kedudukan dan Kewenangan Desa", dalam Http:// www.iaincirebon.ac.id, akses 4 Maret 2016.

\section{Peraturan perundang-undangan:}

Undang-Undang Nomor 5 Tahun 1979 tentang Pemerintahan Desa.

Undang-Undang Nomor 32 Tahun 2004 tentang Pemerintahan Daerah.

Undang-Undang Nomor 6 Tahun 2014 tentang Desa.

Peraturan Pemerintah Nomor 72 Tahun 2005 tentang Desa.

Perda Pemprov Maluku No. 14 Tahun 2005 tentang Penetapan Kembali Negeri Sebagai Kesatuan Masyarakat Hukum Adat dalam Wilayah Provinsi Maluku. 
Perda Provinsi Maluku No. 8 Tahun 2011 tentang Penyerahan Urusan Tugas Pembantuan Pemerintah Provinsi Kepada Negeri/ Negeri Administratif/Desa atau Nama Lain.

Perda Kota Ambon No. 3 Tahun 2008 tentang Negeri.

Perda Kabupaten Maluku Tengah No. 1 Tahun 2006 tentang Negeri.

\section{Tulisan yang tidak diterbitkan}

Thomas Havye Wattimena, Pengawasan Dewan Perwakilan Rakyat Daerah Terhadap Implementasi Peraturan Daerah Nomor 1 Tahun 2006 Tentang Negeri di Kabupaten Maluku Tengah

Ronal Alfredo, Hafied Cangara dan Mahmud Tang, Lembaga Adat Saniri Sebagai Forum Komunikasi dalam Penyelesaian Masalah Publik di Ambon (2006)

JK Matuankottaa dan Darmini Mawardi, Tinjauan Kedudukan dan Fungsi Kepala Persekutuan Hukum Adat dalam Sistem Pemerintahan Desa Dewasa Ini: Studi di Kabupaten Dati II Maluku (2000)

Jemmy Jefry Pietersz, Sengketa Kewenangan antara Pemerintahan Daerah Maluku Tengah dengan Meneteri Dalam Negeri: Telaah Putusan Mahkamah Konstitusi Perkara Nomor: 1/SKLN-VIII/2010.

Sri Zul Chairiyah, Nagari Minangkabau Dan Desa di Sumatra Barat".

BPS Kota Ambon, Rencana Kerja Pemerintahan Kota Ambon Tahun 2014.

BPS Maluku Tengah, Maluku Tengah dalam Angka Tahun 2014. 